(6)

\section{OPEN ACCESS}

Respiratory Medicine, Kyorin university, Mitaka, Japan

Correspondence to Dr Takeshi Saraya sara@yd5.so-net.ne.jp

Accepted 25 October 2017

\title{
Critical pitfall: another cause of wheezing
}

\author{
Takeshi Saraya, Hiroki Nunokawa, Mitsuru Sada, Hajime Takizawa
}

\section{DESCRIPTION}

An 87-year-old woman was referred to our hospital with progressive dyspnoea on effort over the previous 2 weeks. She had been treated for rheumatoid arthritis with oral prednisolone $(5 \mathrm{mg} /$ day) and tacrolimus ( $2 \mathrm{mg} /$ day). At her first visit, vital signs and physical examination were normal except for slight rhonchi in anterior lung fields. Chest radiograph showed slight cardiomegaly, but no abnormal lesions were noted in either lung (figure 1A). Echocardiography demonstrated no evidence of congestive heart failure. She was thus diagnosed with cough variant asthma and/or asthma, and treated with inhaled budesonide $(400 \mu \mathrm{g} /$ day $)$. However, 10 days later, she returned to our hospital because of increasing dyspnoea. She had tachypnoea (30 breaths/min), and intermittent wheezes emerged in both the cervical (online supplementary audio 1) and left tracheobronchial areas. Additionally, the left bronchovesicular sound (online supplementary audio 2) apparently decreased than that of right tracheobronchial area (online supplementary audio 3).

On the same day, thoracic CT revealed a mediastinal tumour (figure $1 \mathrm{~B}, \mathrm{C}$ ) that compressed and/

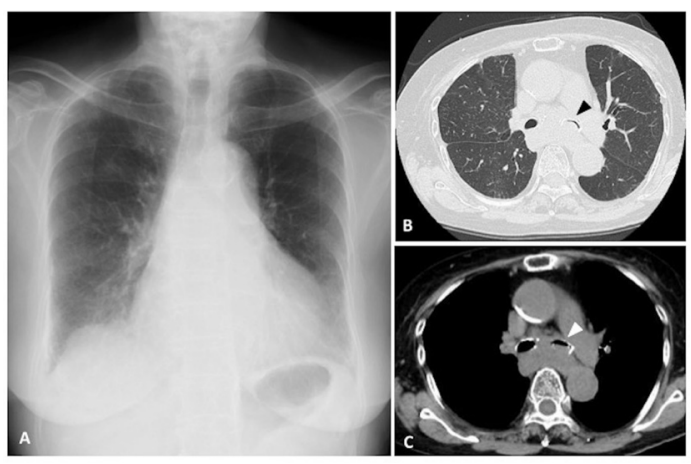

To cite: Saraya T, Nunokawa $\mathrm{H}$, Sada M, et al. BMJ Case Rep Published Online First: [please include Day Month Year]. doi:10.1136/bcr-2017223147

\section{CrossMark}

Figure 1 Chest radiograph taken at the first visit appeared normal except for slight cardiomegaly (A). Thoracic CT demonstrated that the mediastinal tumour compressed the left main bronchus, which partially invaded the bronchial lumen $(B, C)$.

\section{Learning points}

- General physicians should always be aware of the possibility of tracheal/bronchial stenosis due to malignant neoplasms whenever they encounter patients who wheeze.

- Auscultation can be changeable over a short interval of time, but careful auscultation should be performed for appropriate diagnosis.

- The intensity of tracheobronchial sound from bilateral lung fields should be compared in patients with respiratory symptoms.

or partially invaded the left tracheal lumen, thereby generating the intermittent wheezes that radiated to the cervical area.

This case reminds us of the critical pitfalls for wheezing resembling asthma ${ }^{1}$ and the power of careful auscultation for appropriate diagnosis. ${ }^{2}$

Contributors TS and HN made the manuscript. TS, HN, MS and HT managed the patient.

Competing interests None declared.

Patient consent Obtained.

Provenance and peer review Not commissioned; externally peer reviewed.

Open Access This is an Open Access article distributed in accordance with the Creative Commons Attribution Non Commercial (CC BY-NC 4.0) license, which permits others to distribute, remix, adapt, build upon this work non-commercially, and license their derivative works on different terms, provided the original work is properly cited and the use is non-commercial. See: http://creativecommons.org/licenses/by-nc/4.0/

(C) BMJ Publishing Group Ltd (unless otherwise stated in the text of the article) 2017. All rights reserved. No commercial use is permitted unless otherwise expressly granted.

\section{REFERENCES}

1 Nakajima A, Saraya T, Takata S, et al. The saw-tooth sign as a clinical clue for intrathoracic central airway obstruction. BMC Res Notes 2012;5:388

2 Minami T, Minami A, Manzoor K, et al. Modern technology in respiratory medicine: lung ultrasonography-is it time for the stethoscope to give up its throne? Pulm Res Respir Med Open J 2016;3:55-6. 
Copyright 2017 BMJ Publishing Group. All rights reserved. For permission to reuse any of this content visit http://group.bmj.com/group/rights-licensing/permissions.

BMJ Case Report Fellows may re-use this article for personal use and teaching without any further permission.

Become a Fellow of BMJ Case Reports today and you can:

- Submit as many cases as you like

- Enjoy fast sympathetic peer review and rapid publication of accepted articles

Access all the published articles

- Re-use any of the published material for personal use and teaching without further permission

For information on Institutional Fellowships contact consortiasales@bmjgroup.com

Visit casereports.bmj.com for more articles like this and to become a Fellow 